\title{
INTERNALIZATION OF STUDENTS' NATIONALISM SENSE THROUGH OUTBOUND LEARNING BASED ON LOCAL WISDOM
}

\author{
Yulis Jamiah $^{1)}$, Fatmawati $^{2)}$, Endang Purwaningsih ${ }^{3)}$ \\ 1) Universitas Tanjungpura, Pontianak, Indonesia \\ E-mail: yulis.jamiah@fkip.untan.ac.id \\ 2) Universitas Tanjungpura, Pontianak, Indonesia \\ E-mail:fatma_indahnurfitri@yahoo.com \\ 3) Universitas Tanjungpura, Pontianak, Indonesia \\ E-mail: endangpurwaningsih.upi@gmail.com
}

\begin{abstract}
Outbound learning is a system that aims to assist students' learning process, contains a series of activities designed in the open nature, thus influencing and supporting the students' internal learning processes. Learning processes that are appropriate and attractive to students will encourage them to optimize their potential. The potential of local wisdom which is owned by students can be developed, have strategic value to maintain national defense, can strengthen nationalism sense, and can build national faith identity. Students as social agents who function to conserve the values of local wisdom and as a social asset that is useful to bring up a nationalism sense. The value of local wisdom implemented in learning must be based on assets of local cultural values and open to global knowledge and technology. Internalization of the values of local wisdom derived from cultural products and community works as learning media, is useful to bring up nationalism awareness. The values of local community wisdom are still conserved from generation to generation by the community as a moral responsibility to keep the tradition from becoming extinct.
\end{abstract}

Keywords: Nationalism Sense; Outbound Learning; Local Wisdom

\section{INTRODUCTION}

The values of Indonesia's famous ancestors and never worn until now, namely: courtesy, hospitality, honesty and uphold the spirit of togetherness or "cooperativeness" as well as the price of mutual respect the dignity of others. These values constitute the cultural heritage and national character as well as forming the civilization of Indonesia. This civilization needs to continue to be preserved and maintained its presence in the life of the nation and society every day. But in reality, the impact of globalization causes a lot of positive and negative effects. The problem is not correct if viewed as a trivial problem that is only able to be underestimated. The proliferation of globalization leads to a fading sense of nationalism in Indonesia.

Globalization is accompanied by the development of information technology that has resulted in a fading sense of nationalism. Fading sense of nationalism creates the nation's image in the eyes themselves are getting worse or it could be made public spirit Indonesia has been contaminated by the culture from the outside. Thus, in its development, as the Indonesian people should survive facing future problems without fear of losing the image of the nation itself. Therefore, it can be done to strengthen the sense of nationalism of self and others, because of a sense of nationalism is the key to unite all the people of Indonesia.

Strengthening the spirit of nationalism among people who live in areas that are in the national interest perspective is considered strategic, such as the border area. This can be done to minimize the cultural gap in the region through education and awareness program that involves the local communities. Border communities, especially school students as social agents whose function is to preserve cultural products that contain local wisdom values, because the function of preserving social capital fosters nation nationalism. The great value that should be derived from the values of the ancestral culture of the local wisdom (Robert, 2013). The values of indigenous communities need attention to be preserved from generation to generation by the people 
who constitute a moral responsibility to keep the tradition from extinction. Local knowledge is a product of past cultures that should continuously hold onto life. Although local worth, but the value contained in it is considered a very universal (Sartini, 2004).

Furthermore, what can be done by the people of Indonesia, especially educators (teachers) to help solve the problem of the crisis of values of this nation? One way to do this is to internalize the values of local wisdom in the learning process. This method is considered relevant because the teacher is the spearhead for actualizing their abilities, and realize the implementation of education. Through the process, with the hope of forming students who take pride in their nation. They are promoting ethics in social behavior in society. Eventually gained a reliable future generation.

The results of previous studies relating to local wisdom at the border: (1) Rahmaniah et al. (2010) described the importance of human resource development especially informal education for the alleged index of human resource development of border communities is undervalued, it would threaten the sovereignty of Indonesia; (2) Rochmawati et al. (2013) stated that local wisdom border serves as a bulwark in maintaining the border regions of threats and interference from outside parties, while studies in this research lie in the values of local wisdom serve as the foundation of character education students to foster a sense of nationalism through outbound learning model which also serves to maintain the security of the border region from outside interference.

Based on the description above, questions will be formulated to be discussed in this paper, namely: "As to whether the strengthening of nationalism students through learning outbound based local moral values, especially for students in the school of Jagoi Babang border?" With the aim of students and teachers understand that a sense of nationalism can be grown or instilled through local cultural products that contain local wisdom values.

\section{Methodology}

The method used in this research was descriptive analysis method. This method provided an overview and information in a clear, objective, systematic, analytical, and critical about the values of local wisdom derived from local cultural products and feet work Dayak Bidayuh Border West Kalimantan, precisely in the Border of Jagoi Babang Bengkayang (Bordered Indonesia - Malaysia). This study used a qualitative naturalistic approach because the considered problem concerning matters of ongoing naturally in traditional institutions held by the public. To obtain data or information, both primary and secondary categories, the authors used the technique in-depth interviews, observations, and documentation study. Furthermore, the literature survey was, (1) conducting a theoretical analysis of the types of artifacts by Franssen et al. (2013), exploring the values of local wisdom derived from cultural products and cubits of works; (2) analyzing the theory of trees by Cheng (2000), has strong roots as the foundation for the strengthening of a sense of nationalism, and the values of local wisdom in terms of instilling a sense of nationalism students.

\section{RESULTS AND DISCUSSION}

Planting values routinely through habituation, of course with the intention that these values are internalized and polarized to the soul or heart of students. It's like Lickona's view (1991: 51), the character was formed through a process of knowing the good, feeling good, acting the good. This view gives the sense that the establishment and development of character through the process of understanding the values, appreciate or believe in their value, and embody these values in action.

Relevant approaches to implement a model that raises the effective learning required steps: (1) experience; (2) reflect; (3) form concept; and (4) test concept (Boyett in Ancok, 2002). Measures to internalize and actualize values of local wisdom in outbound learning to strengthen the sense of nationalism as follows:

1) Formation of experience (experience), in this step the students observe representations derived from cultural products and feet work of Dayak Bidayuh. Direct experience is a means to generate intellectual experience, effectual experience, and physical experience in students.

2) Contemplation experience (reflect), in this step the teacher facilitates students to express the experience that is felt by the observations intellectually, effectual so finding the values of local wisdom.

3) Formation of the concept (concept form), in this step the teacher facilitates students to find the meaning of intellectual experience, effectual so that students can find a relationship between the values of local wisdom with the concept of nationalism.

4) Concept testing (test concept), in this step the teacher and students discuss the return and accompanied by questions about the relationship between the values of local wisdom with the concept of nationalism.

The process of extracting values of local wisdom that used in learning to strengthen students' sense of nationalism, the stages include: (1) explore cultural products in an area; 2) identify and analyze theoretically and practically related to the values of local wisdom contained in the cultural products; and (3) to analyze the values of local wisdom that can reveal the concept of nationalism. Exposure data contained in Table I is a study based on the three stages. Data source "the values of local wisdom contained in the Cultural products of Dayak Bidayuh Jagoi Babang Border of Bengkayang District" that had been exposed in Table I is obtained through interviews with the Chairman of the Customary Council named Nohang, and the Customary Secretary named Kasminto (Oral information from the interview on February 20, 2018). The relationship between the activity of presenting local cultural products with the process of actualizing and internalizing the values of local wisdom to strengthen a sense of nationalism was presented in Table I. 
TABLE I



\begin{tabular}{|c|c|c|}
\hline No. & $\begin{array}{c}\text { Products of Local } \\
\text { Cultural }\end{array}$ & Local Wisdom Values \\
\hline 1. & $\begin{array}{l}\text { The Pangah } \\
\text { traditional house }\end{array}$ & $\begin{array}{l}\text { - The traditional house describes a sacred or holy place where Jubata (God) resides } \\
\text { and symbolizes their love and respect to the ancestors. } \\
\text { - The traditional house building has a total of } 9 \text { pillars which symbolically means } \\
\text { that the number } 9 \text { is considered the highest number that has a lucky value for the } \\
\text { villagers. } \\
\text { - The traditional house has a function as a place to unite residents in worshiping the } \\
\text { spirits of the ancestors. }\end{array}$ \\
\hline 2 & $\begin{array}{l}\text { Betang house or } \\
\text { Radankg or Boli } \\
\text { Omu }\end{array}$ & $\begin{array}{l}\text { Betang House consists of } 20 \text { to } 40 \text { doors with one stairway to go up and down, can } \\
\text { be closed and raised to maintain security. Longhouses are built with tall poles to } \\
\text { avoid attacks by wild animals or enemies. The Betang House became a solid } \\
\text { symbol of communal life for the Dayak people not only as a legendary expression } \\
\text { of the life of the ancestors but also as a full and concrete statement about village } \\
\text { governance, social organization, and social systems became the central point of the } \\
\text { lives of its citizens. The system of cultural values that results from the process of } \\
\text { longhouse life, concerns the meaning of human life; the meaning of work; works } \\
\text { and deeds; perception of time; human relations with nature; about relationships } \\
\text { with others. Betang house is the center of their culture because that is where all } \\
\text { activities and all life processes go from time to time. They love peace in a } \\
\text { harmonious community so they try hard to maintain the tradition of this longhouse. } \\
\text { The main value that stands out in life at the Betang house is the value of } \\
\text { togetherness (communalism) among the residents who inhabit it, regardless of the } \\
\text { differences they have. The existence of the Betang traditional house from the } \\
\text { inland Dayak tribe imaged the togetherness and tolerance. }\end{array}$ \\
\hline
\end{tabular}

3. Hornbills According to the oral tradition of the Dayak people, the hornbill is the incarnation of the skipper who is considered magic. Hornbills symbolize the strength, might, and authority and symbolize greatness and glory. The symbolic meaning of the Dayak is that someone is synonymous with power and authority, therefore in society to unite with one another to be strong, to live in love, and to work together.

4. Shield or Telawang The shield serves as a complement to self-defense tools when fighting, and as a complement in dances. It is said that the carving has a magical power that can arouse the spirit to make people who bear it strong. Telawang as a complement to the saber is also considered a magical object that can give strength to its owner. Telawang is a cultural object that was born from the Dayak people's belief in magical powers. Telawang contains symbolic meaning which is a symbol of strength and defense. Besides that, it means the knight and authority, for the owner of Telawang which is combined with the saber, shows that the owner is a brave and strong person.

5. Saber or Jepal Saber contains symbolic meanings that are considered valuable items and contains magical powers that contain magical values. The magic of saber is not only obtained from the process of making it through certain rituals but also obtained from headhunting (the beheading of opponents). The saber that is considered sacred is the antique saber from the ancestors that were used to head, so the saber is considered a sacred object. The saber is used for traditional events and is used as a tool to treat patients (sick people) by traditional healers. The saber is a symbol of a knight, a symbol of guardianship, responsibility, and maturity for its owner. Saber also contains symbols as magical objects that contain magical, for people who have them are considered to be able to bring blessing or luck.

6. Spear The spear is a traditional Dayak weapon that functions as a weapon for warfare (mengayau) protecting itself from harmful disturbances and hunting animals in the forest and fishing in rivers. Like the saber and Telawang, spears are war weapons that have magical and sacred powers. The making of spears comes from the Nibukng tree. This wood has magical and sacred powers, ie to cut and take this tree must perform certain ritual ceremonies in advance so as not to get harmed to those who cut down or who take it. In addition, Nibukng is believed to be able to dilute the powers possessed by someone, so that Nibukng is considered to have magical powers.

7. Gong Gongs have the myth and ethnic Dayak belief that gongs are believed to accompany human descent from the sky and gongs are considered valuable objects
Concept a sense of Nationalism that Revealed Maintain and preserve ancestral values (ancestral love)

The value of unity and togetherness, family values, the values of tolerance, and the value of love for the homeland

The value of unity, togetherness, patriotic, and value of wildlife conservation

Value nation strong and firm on the establishment, the value of self-reliance

The value of a knight, the value of authority or the value of self-esteem, magical values or values that have an element of metaphysics, value of strength, and value of defense

The value of strength and knighthood, the value of courage and authority, the value of never giving up

The value of unity, togetherness, patriotism 


\begin{tabular}{|c|c|c|}
\hline No. & $\begin{array}{c}\text { Products of Local } \\
\text { Cultural }\end{array}$ & Local Wisdom Values \\
\hline & & $\begin{array}{l}\text { of high economic value. Gong functions as a tool to communicate with ancestral } \\
\text { spirits. The beliefs of Dayak people who adhere to Kaharingan religion (Dayak } \\
\text { ethnic ancestral religion), gongs are sacred objects. Gong, each ritual ceremony } \\
\text { becomes a dominant musical instrument, both to accompany traditional shamans or } \\
\text { ceremonial leaders, dance and sing mantras, gather the community so that it is } \\
\text { heard to a distance. In addition, Gong is used to informing the wider community } \\
\text { about an event or party that is carried out by one family, and from one village to } \\
\text { another. Likewise, when there is an event of death while the body is still buried in } \\
\text { a funeral home, Gong is played to deliver the spirits of the deceased to the spirit } \\
\text { realm. }\end{array}$ \\
\hline
\end{tabular}

8 Gawai Dayak Event Gawai Dayak is held in a longhouse. The Dayak Bidayuh offering is called Boli Omu. Gawai Dayak ritual activities, starting with dances by young men and traditional leaders and village elders, while bringing offerings to be placed in the offering hut. Traditional ceremonial rituals used to express gratitude and gratitude to Jubata (the Creator) for harvests have been obtained for a year and expect abundant results the following year. They also pray that they will always be given health and safety. The procedure for the Gawai activities by the customary Chair recites a special spell for this ceremony and smears the blood of the roosters on offering material or offerings. The requirements for the traditional Gawai event include betel nut, tumpe, pulut, rendai, salt, rice, eggs, chicken's head, lime, ase maneh, rhombus, sembakau, floating cigarette leaves, and several others. Before implementing Gawai, the community prepares traditional foods such as pulut or lemang, rendai, tumpe, shake flower, and traditional drinks such as tuak water that will be served at the time of the device. Nyangahathn is referred to as the main procedure for religious expression of the Dayak, and is a central part of every form of ceremony. The Nyangahatn stage consists of (1) Matik, informing the family's wishes to Awa Pama (ancestral spirit) and Jubata; (2) Ngalantekatn, a request that all families involved be saved; (3) Mibis, aiming that everything (defilement) is dissolved and flown from the family and buried as the sun goes west; and (4) Ngadap Buis, namely the stage of receiving offerings (Buis) by Awa Pama and Jubata, to express gratitude and obtain blessings or sanctification (purification) of all things that are not pleasing, including the calling of all living (lost) souls so that calm and serene.
Planting a sense of nationalism for students in the education unit is a job that most needs attention because students are the future generation that is prepared as a future successor. Efforts to form the next generation of fully covering all aspects of life, including moral, aesthetic, and values, requires several steps such as the review of the formation of character or personality of students as the expectations set out in the four pillars of education UNESCO, such as: (1) learning to know, namely educate students to have the ability to think critically and systematically in order to understand ourselves, others, and the world; (2) learning to do, namely to educate students to be able to apply what is known and understood in practice to overcome the problems encountered; (3) learning to be, namely to educate students to be himself authentic and independent, have an attitude of consistency, adhering to the principle that not swayed by vested interests and insistence on the environment; and (4) learning live together, that is to educate students to have an attitude of tolerance, understanding the differences and uniqueness between them, were able to work together so that they appear fraternity among them (Sugiarto, 2008: 344; Elmubarok, 2007: 41).

Students according to nature has individual dimensions and social dimensions. Individual dimensions must be developed so that students can become a man capable of independent, to think for themselves, to have a competitive spirit and creative, in the end, the students can achieve optimal self-fulfillment. The social dimension needs to be established and developed through the learning process because the social dimension can help to raise awareness of students to realize that they can grow and thrive in a corporate context with the other fellow in the community. Through the process of learning to internalize the values of wisdom, potential students both individually and socially can be facilitated to be developed. Students as a social agent that serves to preserve the values of local wisdom and as a useful social capital to foster a sense of nationalism. Implementing the value of local wisdom in learning must be based on local cultural assets and be open to global knowledge and technology.

The purpose of learning is not the mastery of the material alone, but further process mastery of the material can form a pattern of behavior of the students themselves. Learning is a lasting change in behavior, or the capacity to behave in a certain way, resulting from practice or other forms of experience. Learning criteria, including (1) learning involves changes; (2) learning to survive longer with time; and (3) learning occurs through experience. Learning activities that 
involved mastery and change of knowledge, skills, strategies, beliefs, attitudes, and behavior (Dale H. Schunk, 2012).

According to Phil (2012: 110), the authority and reality were the pillars of learning, the authority could be created, if the teacher can build a high touch on students and thus creating a sense of security and comfort together educators. Conditioning feels safe and comfortable in this study, it needs to consider the elements of authority, namely: (1) recognition and acceptance; (2) affection and tenderness; 3) strengthening; (4) action is to educate; and (5) guidance and exemplary. Reality elements, namely: (1) acquisition of learning materials; (2) the application of learning methods; (3) the use of learning aids; (4) the development of the learning environment; and (5) the implementation of learning assessment.

The establishment of good student behavior requires educators to loved his profession for the progress of the student and will not tear down the pillars of learning. Chairil (2012: 9) stated professional educators naturally reflect behavior that can be emulated by students, such as speaking wisely, properly and correctly, with the language beautiful things, and with manners will cultivate the mind and positive attitude, foster familiarity and strengthen the brotherhood, cultivate sympathy and empathy, distancing the speaker from feeling depressed or intimidated.

Learning by clicking internalize the values of local wisdom can be used as a means of preserving the region's potential. Understanding the values of local wisdom must be explored from the potential of the region, for example through the work of his ancestors. The potential of the area is a potential specific resource owned by a particular region. Students interact in the learning process, not like an empty bottle, but they already carry cultural values that are taken from the family and community. Wise teachers must be able to actualize the values of their local wisdom in the learning process. A study that will be implemented in the learning process by elaborating local wisdom value through local cultural products to express the concept of students nationalism. Why need to internalize the values of local wisdom in learning? One reason is that local wisdom in the region will, in turn, be able to lead students to love the cultural products of their area. The love of students in the region will realize regional resilience. Resilience is the ability of a local area demonstrated by the ability of citizens to organize themselves following the concept that to be true with a strong soul, the spirit is high, and by utilizing the nature wisely.

Implementation of the value of local wisdom in learning, in the hope of civilized behavior of students formed locally but open to global knowledge and technology. According to Rachman (2010), built students' behavior or attitudes need at least three things, namely: exemplary, habituation, and correction/control. Behaviors of teachers in building behaviors are qualified, through (1) exemplary, the teacher when conducting the learning process must expose values, such as courage, honesty, confidence, responsibility, humility, mutual respect, etc. so that students can be emulated. Because students will emulate the process of imitating, seeing, hearing, and following; (2) habituation, the teacher while doing the learning process must get accustomed to repeating the values internalized in students through behavior; (3) correction/control, a teacher while doing the learning process continues to provide awards (reward) to students who excel as an encouragement/motivator, and sanctions (punishment) for students who are not paying attention. This is all, can not be separated from the consciousness of the task of teachers who not only make students become proficient, but also equip them with the values of life to prepare for the challenges of the future.

\section{CONCLUSIONS}

Implementation of the value of local wisdom in learning should be based on the values asset of the local culture that opened to global knowledge and technology. The internalization of the values of local wisdom derived from cultural products and the work of the community as a learning medium can foster nationalism awareness. Preservation of the values of local wisdom from generation to generation by the people today as a moral responsibility to keep the tradition from extinction.

Creativity teachers to actualize the values of local wisdom in the learning process was needed to establish a good character and a strong student. Teachers were committed to professionalism, certainly not cease to develop skills according to their expertise. In addition to a teacher's creativity, exemplary attitude, habituation, and correction/control required to uphold the pillars of learning because that attitude will appear and emit educational value. Values are always radiated, if educators do not only act as the transferor is the subject of intellectual knowledge of their students, but rather to empower educators and their students develop subject knowledge fully/comprehensively.

\section{ACKNOWLEDGMENT}

This research was funded through 2019 Applied Research with contract number 101/SP2H/LT/DRPM/2019 dated March 11, 2019, therefore many thanks were expressed to the Ministry of Research, Technology, Higher Education of the Republic of Indonesia. We would also like to thank the validator who worked hard to examine the contents of this textbook and provide many suggestions.

\section{REFERENCES}

Chairif E. (2012) Peranan Bahasa Melayu dalam Membangun Karakter Bangsa. Bahan Seminar Nasional di Hotel Aston Pontianak, 5-6 Juni 2012.

Cheng, Y.C. (2000). Fostering Local Knowledge and Wisdom in Globalized Education: Multiple Theories, The $8^{\text {th }}$ International Conference on "Globalization and Localization Enmeshed: Searching for a Balance in Education". 
Dale H. Schunk. (2012). Learning Theories An Educational Perspective (Teori-teori Pembelajaran Perspektif Pendidikan), Edisi ke-6. Penerbit: Pustaka Pelajar.

Elmubarok, Z. (2008). Membumikan Pendidikan Nilai. Mengumpulkan yang Terserak, Menyambung yang Terputus, dan Menyatukan yang Terputus. Bandung: Alfabeta.

Franssen, Maarten., Peter Kroes, Thomas A.C. Reydon, and Pieter E. Vermaas. (2013). Artefact Kinds: Ontology and the Human-Made World. Springer International Publishing Switzerland 2014, (eBook) (www.springer.com)

Phil Yanuar Kiram. (2012). Profesi Pendidik Seutuhnya dalam Perseptif Penyiapan Manusia Indonesia Generasi 2045. Materi Konvensi Nasional Pendidikan Indonesia (KONASPI) VII 2012 di Yogyakarta, 31 Oktober - 3 November 2012. Penerbit: UNY Press.

Rahmaniah dkk., (2010). Pembangunan Perbatasan dan Keamanan Masyarakat Pernatasan Kabupaten
Sambas. Jurnal, 13(3), 79, edisi Juli 2010. ISSN: 0853-2028. Pontianak: Lembaga Penelitian Universitas Tanjungpura.

Rochmawati, Ida., dkk. (2013). Penguatan Kehatahan Sosial Masyarakat Perbatasan melelui Sinergitas Kearifan lokal untuk mengantisipasi bentuk pelanggaran. Studi di Perbatasan Jagoi Babang Kabupaten Bengkayang. Makalah Hasil Penelitian Stranas 2013. Pontianak: Fisip Universitas Tanjungpura

Robert Sibarani. (2013). The character building based on local wisdom. http://www.museum.pusakanias.org/2013/02/pembentukan-karakter-berbasiskearifan.html [on-line diakses 29 April 2013].

Sartini. (2004). Menggali Kearifan Lokal Nusantara Sebuah Kajian Filsafati, Jurnal Filsafat, 37(2), UGM, Edisi Bulan Agustus 2004.

Sugiarto, B. (2008). Humanisme Humaniora: relevansinya Bagi Pendidikan. Yogyakata \& Bandung: Jalasutra. 